\title{
ANALISIS KEMAMPUAN BERPIKIR KRITIS MATEMATIS SISWA BERDASARKAN TIPE KEPRIBADIAN YANG DOMINAN DI KELAS XI MIA SMA NEGERI 2 KOTA JAMBI
}

\author{
Rina Febriana ${ }^{1}$, Zulyadaini $^{2}$, Aisyah $^{3}$ \\ Program Studi Pendidikan Matematika, FKIP, Universitas Batanghari ${ }^{1,2,3}$ \\ Jl. Slamet Riyadi No.1 Broni Jambi \\ e-mail: -
}

\begin{abstract}
ABSTRAK
Matematika mampu melatih pemikiran siswa yang logis, analitis, sistematis, kritis, dan kreatif. Kemampuan berpikir kritis matematis adalah kemampuan yang mendukung berbagai kemampuan berpikir matematis lainnya. Penelitian ini termasuk jenis penelitian kualitatif yang menggunakan metodologi penelitian deskriptif kualitatif. Penelitian ini akan dilakukan pada siswa kelas XI MIA SMA Negeri 2 Kota Jambi. Hal yang dijelaskan dalam penelitian ini adalah berpikir kritis matematis siswa berdasarkan tipe kepribadian dominan pada solusi program linier. Hasil tes kepribadian instrumen diadaptasi dari pola kepribadian oleh Lana Bateman menemukan 40 siswa dominan yaitu tipe kepribadian dahak. Selanjutnya, berdasarkan teknik pengambilan sampel yaitu teknik purposive sampling, 2 siswa diambil sebagai subjek penelitian yaitu siswa flegmatik dengan tingkat kemampuan berpikir kritis tertinggi yang disebut siswa flegmatik pertama dan siswa flegmatik dengan kemampuan berpikir kritis level terendah disebut siswa flegmatik kedua. . Dari hasil yang diperoleh dapat disimpulkan bahwa mahasiswa flegmatik pertama memiliki tingkat keterampilan berpikir kritis sangat kritis dan siswa flegmatik kedua memiliki tingkat berpikir kritis kritis tidak kritis. Ini berbanding terbalik antara kemampuan berpikir kritis dan tipe kepribadian apatis. Mahasiswa flegmatik pertama dengan kategori flegmatik cukup memiliki pemikiran matematika kritis kritis dan mahasiswa flegmatik kedua dengan kategori flegmatik sangat tinggi / dominan, kemampuan berpikir kritis kritis tidak kritis.
\end{abstract}

Kata kunci:

Empat Jenis Temperamen; Kemampuan Berpikir Kritis Matematis.

\begin{abstract}
Math is able to train logical, analytical, systematic, critical, and creative thinking of students. Mathematical critical thinking ability is a capability that supports a variety of other mathematical thinking abilities. This research includes the type of qualitative research that uses descriptive qualitative research methodology. This research will be conducted on the students of class XI MIA SMA Negeri 2 Kota Jambi. The thing described in this research is the students' mathematical critical thinking based on the dominant personality type on linear program solution. The results of personality tests of the instrument adapted from the patterns of personality by Lana Bateman found 40 dominant students that is the type of phlegmatic personality. Furthermore, based on sampling technique that is purposive sampling technique, 2 students are taken as research subjects ie phlegmatic students with the highest level of critical thinking ability called first phlegmatic students and phlegmatic students with the lowest level of critical thinking ability is called second phlegmatic student. From the results obtained can be concluded that the first phlegmatic students have the level of critical thinking skills are very critical and the second phlegmatic students have a critical level of critical thinking is not critical. This is inversely between the ability to think critically and the type of phlegmatic personality. The first phlegmatic student with enough phlegmatic category has critical critical mathematical thinking and the second phlegmatic student with very high / dominant phlegmatic category, critical critical thinking ability is not critical.
\end{abstract}

Keywords:

Four Temperament Types; Mathematical Critical Thinking Ability. 


\section{$\pi$ (Phi)}

\section{PENDAHULUAN}

Matematika merupakan salah satu disiplin ilmu yang dapat meningkatkan kemampuan berpikir dan berargumentasi, memberikan kontribusi dalam penyelesaian masalah sehari-hari dan memberikan dukungan dalam pengembangan ilmu pengetahuan dan teknologi (Susanto, 2013). Hal ini senada dengan yang tercantum pada standar isi untuk satuan pendidikan dasar dan menengah, yaitu Permendiknas Nomor 22 Tahun 2006 menyebutkan bahwa mata pelajaran matematika mendasari perkembangan kemajuan teknologi, mempunyai peran penting dalam berbagai disiplin, dan memajukan daya pikir manusia.

Kemampuan berpikir kritis siswa juga erat kaitannya dengan kepribadian atau watak yang dimiliki siswa. Kepribadian merupakan gambaran total tentang tingkah laku individu yang terorganisasi (Dashiell, 2016). Kepribadian dapat mempengaruhi bagaimana seseorang berperilaku, berfikir, maupun berinteraksi dengan sekitar (Dr. William Moulton Marston dalam Edysen Shin, 2013). Kepribadian yang dimiliki peserta didik berbeda-beda dan demi suksesnya usaha untuk mendidik mereka, perlulah kita mengenal kepribadian mereka (Suryabrata, 2010) dan setiap siswa memiliki tipe kepribadian yang berbeda, sehingga proses berpikir siswa dalam menyelesaikan masalah matematika juga berbeda (Agustina, 2014)

Ada banyak teori tipe kepribadian siswa. Salah satu teori yang sering digunakan dan terus dikembangkan adalah teori kepribadian oleh Hippocrates dan Galenus yang ditinjau dari segi temperamen. Menurut teori tersebut, kepribadian digolongkan menjadi empat yaitu: sanguinis, choleris, melancholis, dan phlegmatis. Tipe choleris memiliki sifat mudah berubah pendirian, tipe melancholis bersifat pemuram dan mudah kecewa, dan tipe phlegmatis berpenampilan tenang dan setia.

Berdasarkan hasil wawancara diperoleh informasi bahwa pengalamannya selama ia mengajar, pada umumnya siswa belum mampu menyaring informasi dari soal dan mengerjakannya dengan memadukan pengetahuan-pengetahuan siswa sebelumnya yang terkait dengan soal. Dapat dibayangkan jika siswa tidak mampu untuk menyaring informasi dari soal dan mengerjakan tanpa memadukan pengetahuan sebelumnya dapat dipastikan kemampuan dalam berpikir kritis siswa tersebut masih rendah. Oleh karena itu menurut beliau hal tersebut dikarenakan kurangnya kemampuan berpikir kritis matematis siswa.

\section{METODE PENELITIAN}

Adapun metode penelitian yang digunakan dalam penelitian ini adalah metode kualitatif. Penelitian jenis ini termasuk jenis penelitian kualitatif yang menggunakan metodologi pendekatan penelitian deskriptif. Penelitian ini akan dilaksanakan pada siswa SMA Negeri 2 Kota Jambi. Hal yang dideskripsikan dalam penelitian ini adalah analisis kemampuan berpikir kritis matematis siswa berdasarkan tipe kepribadian yang dominan pada penyelesaian soal program linear. Pendeskripsian ini ditelusuri melalui proses berpikir kritis siswa dalam menyelesaikan soal matematika yaitu dengan menganalisis hasil pekerjaan siswa dalam merumuskan soal, menyelesaikan soal yang diberikan dan hasil wawancara yang dilakukan.

Wawancara dalam penelitian ini bertujuan untuk mengungkapkan gambaran kemampuan berpikir kritis matematis siswa tipe kepribadian yang dominan pada penyelesaian soal program linear. Penelitian ini dilaksanakan di SMA Negeri 2 Kota Jambi kelas XI MIA tahun ajaran 2017/2018. Waktu penelitian dilaksanakan pada semester ganjil tahun ajaran 2017/2018. 


\section{$\pi$ (Phi)}

Subjek penelitian ini adalah siswa yang memiliki tipe kepribadian yang dominan. Pemilihan subjek penelitian ini berdasarkan hasil tes kepribadian yang diadopsi langsung dari instrumen yang diadaptasi dari pola-pola kepribadian oleh Lana Bateman (Littauer, 2011) yang akan menentukan siswa yang memiliki tipe kepribadian yang dominan. Pada penelitian ini teknik pengumpulan data yang digunakan adalah triangulasi. Triangulasi adalah teknik pengumpulan data yang bersifat menggabungkan dari berbagai teknik pengumpulan data dan sumber data yang telah ada. Triangulasi yang digunakan adalah triangulasi teknik.

Instrumen lainnya dalam penelitian ini adalah tes kepribadian, konstruksi dan isi tes kepribadian di adaptasi dari polapola kepribadian oleh Lana Bateman (Littauer, 2011) langsung dari instrumen yang telah disusun melalui penelitian, pengamatan dari hari ke hari terhadap watak orang lain, memberikan penyuluhan tentang kepribadian dan setelah dibicarakan dalam seminar berkali-kali. Soal dalam tes kepribadian ini berjumlah 40 soal, yaitu terdiri dari 20 soal tentang kekuatan dan 20 soal tentang kekurangan dari tipe-tipe kepribadian yang ada. Dalam tes kepribadian ini, setiap soal terdiri dari empat pilihan kata yang harus dipilih salah satu. Pemilihan kata ini berdasarkan sifat dan watak atau kebiasaan yang dimiliki oleh siswa tersebut. Kata mana yang lebih cocok atau sesuai dengan kebiasaan, watak atau kepribadian yang dimilikinya. Definisi kata yang diberikan diadaptasi langsung dari pola-pola kepribadian oleh Lana Bateman (Littauer, 2011)

Pada penelitian ini uji kredibilitas data atau kepercayaan terhadap data hasil penelitian dilakukan dengan triangulasi waktu, yaitu menggunakan pengulangan wawancara, yakni mencari kesesuaian data yang bersumber dari dua masalah yang setara pada waktu yang berbeda.

\section{HASIL DAN PEMBAHASAN Hasil Instrumen Pengumpulan Data}

Hasil pengumpulan data pada penelitian ini adalah tes tipe kepribadian yang diadopsi langsung dari instrumen yang diadaptasi dari pola-pola kepribadian (Personality Plus, 2011) yang akan menentukan siswa yang memiliki tipe kepribadian phlegmatis. Sedangkan instrumen pedoman wawancara digunakan untuk menggali lebih mendalam mengenai kemampuan berpikir kritis matematis siswa. Pertanyaan pedoman wawancara terdiri dari 18 pertanyaan dan disesuaikan dengan indikator kemampuan berpikir kritis.

\section{Hasil Validasi Instrumen Penelitian}

Instrumen pedoman wawancara yang dihasilkan pada penelitian ini disusun berdasarkan indikator kemampuan berpikir kritis yang adaptasi Facione (1994) dalam Jurnal Pendidikan Matematika. Pedoman wawancara ini divalidasi oleh satu orang dosen pendidikan matematika dan satu orang guru mata pelajaran matematika di SMA Negeri 2 Kota Jambi.

\section{Hasil Uji Coba Soal Kemampuan Berpikir Kritis}

Data dalam penelitian ini adalah data yang didapat dari hasil tes kemampuan berpikir kritis matematis siswa. Peserta tes kemampuan berpikir kritis adalah siswa yang memiliki tipe kepribadian phlegmatis yang tersebar di kelas XI MIA 1, XI MIA 2, XI MIA 3, XI MIA 4, XI MIA 5, dan XI MIA 6 SMA Negeri 2 Kota Jambi. Dari hasil uji coba tes kemampuan berpikir kritis tahap 1 dan tahap 2 diperoleh validitas, taraf kesukaran, daya beda, dan reliabilitas. Berdasarkan perhitungan validitas pada lampiran 10 diperoleh soal nomor $1 t_{\text {hitung }}>t_{\text {tabel }}$ yaitu 11,94 > 1,69 hal ini menunjukkan bahwa soal nomor 1 termasuk kategori valid, pada soal nomor 2 diperoleh $t_{\text {hitung }}>t_{\text {tabel }}$ yaitu $15,91>1,69$ soal nomor 2 juga termasuk kategori valid. 


\section{$\pi$ (Phi)}

\section{Hasil Instrumen Pengumpulan Data Siswa}

Untuk mendapatkan siswa yang akan menjadi subjek penelitian oleh peneliti, yaitu siswa yang memiliki tipe kepribadian phlegmatis, maka peneliti menggunakan lembar tes kepribadian yang telah dibuat oleh ahlinya. Pada tanggal 2 Agustus 2017 lembar tes kepribadian ini diberikan kepada siswa kelas XI MIA 1, XI MA 2, XI MIA 3, XI MIA 4, XI MIA 5, dan XI MIA 6 SMA Negeri 2 Kota Jambi yang berjumlah 42 siswa di kelas XI MIA 1, 43 siswa di kelas XI MIA 2, 48 siswa di kelas XI MIA 3, 47 siswa di kelas XI MIA 4, 20 siswa di kelas XI MIA 5, dan 29 siswa di kelas XI MIA 6. Berdasarkan hasil tes yang telah dihitung dan diperiksa oleh peneliti menggunakan perhitungan Lana Bateman, terhadap siswa kelas XI MIA 1, XI MIA 2, XI MIA 3, XI MIA 4, XI MIA 5, dan XI MIA 6 SMA Negeri 2 Kota Jambi hasilnya adalah ditemukan (dapat dilihat pada lampiran 4), 23 siswa bertipe kepribadian lebih dari 1 (campuran), 53 siswa bertipe kepribadian sanguinis, 37 siswa bertipe kepribadian koleris, 37 siswa bertipe kepribadian melancholis, 79 siswa bertipe kepribadian phlegmatis. Karena yang diteliti oleh peneliti hanya tipe kepribadian phlegmatis dengan kategori tinggi saja untuk dilakukan analisis kemampuan berpikir kritis matematis, maka didapat 40 siswa bertipe kepribadian phlegmatis dengan skor diatas 15 saja.

Pada penelitian ini peneliti mengelompokkan kembali dari 79 siswa yang memiliki tipe kepribadian phlegmatis dengan bermacam- macam kategori yaitu rendah, sedang, tinggi dan sangat tinggi seperti pada tabel, peneliti hanya memfokuskan pada tipe kepribadian yang berada pada kategori tinggi dan sangat tinggi saja, atau siswa yang mendapatkan skor hasil tes tipe kepribadian phlegmatis dengan jumlah skor phlegmatis diatas 15 atau pada kategori tinggi.
Jurnal Pendidikan Matematika

Volume 2 Nomor 1 Tahun 2018

\section{Hasil Penelitian Pada Siswa Tipe Kepribadian Phlegmatis Pada Penyelesaian Soal Progam Linier Tahap 1}

Tingkat Kemampuan Berpikir Kritis Matematis Siswa 1 Berdasarkan Tipe Kepribadian Phlegmatis Pada Penyelesaian Soal Program Linier Tahap 1

Dari kutipan wawancara dan hasil jawaban siswa di atas bahwa S.P01 mampu menulis yang diketahui dan ditanyakan dari soal dengan tepat dan lengkap sesuai dengan indikator pertama yaitu menginterpretasi, mampu membuat model matematika dari soal yang diberikan dengan tepat dan memberi penjelasan yang benar dan lengkap sesuai dengan indikator kedua yaitu menganalisis, mampu menggunakan metode yang tepat dalam menyelesaikan soal, lengkap dan benar dalam melakukan perhitungan sesuai dengan indikator ketiga yaitu mengevaluasi, serta mampu membuat kesimpulan dengan tepat, sesuai dengan konteks soal dan lengkap sesuai dengan indikator keempat yaitu menginferensi. Karena S.P01 mampu mengerjakan semua soal dengan sangat baik sehingga S.P01 berada pada tingkatan kemampuan berpikir kritis pada tingkat 3 (sangat kritis).

\section{Tingkat Kemapuan Berpikir Kritis Matematis Siswa 2 Berdasarkan Tipe Kepribadian Phlegmatis Pada Penyelesaian Soal Program Linear Tahap 1}

Dari kutipan wawancara dan hasil jawaban siswa di atas bahwa S.P02 tidak mampu menulis yang diketahui dan ditanyakan dari soal dengan tepat dan lengkap yang artinya S.P02 tidak dapat memenuhi indikator pertama yaitu menginterpretasi, tidak mampu membuat model matematika dari soal yang diberikan dengan tepat dan memberi penjelasan yang benar dan lengkap yang artinya S.P02 tidak mampu memenuhi indikator kedua yaitu 


\section{$\pi$ (Phi)}

menganalisis, tidak mampu menggunakan metode yang tepat dalam menyelesaikan soal, lengkap dan benar dalam melakukan perhitungan yang artinya S.P02 tidak mampu memenuhi indikator ketiga yaitu mengevaluasi, serta tidak mampu membuat kesimpulan dengan tepat, sesuai dengan konteks soal dan lengkap yang artinya S.P02 tidak mampu menginferensi. Sehingga S.P02 berada pada tingkatan kemampuan berpikir kritis pada tingkat 0 (tidak kritis).

Tabel 1. Skor Hasil Tes Kemampuan Berpikir Kritis Tahap 2 Siswa Tipe Kepribadian Phlegmatis

\begin{tabular}{|c|c|c|c|c|c|c|}
\hline \multirow{4}{*}{ No } & \multirow{4}{*}{ Nama } & & $\begin{array}{l}\text { mor } \\
\text { tir } \\
\text { al }\end{array}$ & \multirow{4}{*}{ Total } & \multirow{4}{*}{\multicolumn{2}{|c|}{$\begin{array}{cc} & \text { Tingkat } \\
\text { Kemampuan } \\
\text { Nilai } & \begin{array}{c}\text { Berpikir } \\
\text { Kritis }\end{array}\end{array}$}} \\
\hline & & & 2 & & & \\
\hline & & \multicolumn{2}{|c|}{$\begin{array}{c}\text { Bobot } \\
\text { Nilai }\end{array}$} & & & \\
\hline & & 16 & 16 & & & \\
\hline 1 & $\mathrm{DN}$ & 2 & 2 & 4 & 16 & Tidak Kritis \\
\hline 2 & LR & 16 & 16 & 32 & 100 & Sangat Kritis \\
\hline
\end{tabular}

Berikut akan dipaparkan analisis kemampuan berpikir kritis matematis siswa tipe kepribadian Phlegmatis pada penyelesaian soal program linear di kelas XI MIA SMA Negeri 2 Kota Jambi tahun ajaran 2017/2018. Dua siswa yang terpilih menjadi subjek penelitian telah melakukan tes soal kemampuan berpikir kritis tahap 1 dan melakukan wawancara pertama, selanjutnya kedua siswa yang menjadi subjek penelitian tersebut melakukan tes soal kemampuan berpikir kritis tahap 2 dan melakukan wawancara kedua. Tingkatan kemampuan berpikir kritis matematis siswa tahap 2 tipe kepribadian phlegmatis.

Maka selanjutnya kedua siswa yang memiliki tipe kepribadian phlegmatis yang memiliki tingkat kemampuan berpikir kritis yang berbeda yang diperoleh dari kelas XI MIA 1-6 SMA Negeri 2 Kota Jambi yang telah menjawab tes soal kemampuan berpikir kritis tahap

2 melakukan wawancara yang kedua, adapun subjek yang akan diwawancarai adalah sebagai berikut:
Tabel 2. Subjek Penelitian Untuk Wawancara Kedua

\begin{tabular}{|c|c|c|c|c|c|c|}
\hline \multirow{4}{*}{$\begin{array}{l}\mathbf{N} \\
\mathbf{0}\end{array}$} & \multirow{4}{*}{ Nama } & Bu & $\begin{array}{l}\text { nor } \\
\text { Soal }\end{array}$ & \multirow{4}{*}{ Total } & \multirow{4}{*}{ Nilai } & \multirow{4}{*}{$\begin{array}{c}\text { Kode } \\
\text { Subjek }\end{array}$} \\
\hline & & 1 & 2 & & & \\
\hline & & \multicolumn{2}{|c|}{ Bobot Nilai } & & & \\
\hline & & 16 & 16 & & & \\
\hline 1 & LR & 16 & 16 & 32 & 100 & SP.01 \\
\hline 2 & DN & 2 & 2 & 4 & 16 & SP.02 \\
\hline
\end{tabular}

\section{Pembahasan}

Hasil analisis data tingkat kemampuan berpikir kritis matematis siswa berdasarkan tipe kepribadian phlegmatis menunjukkan bahwa 229 siswa yang diberi tes tipe kepribadian yang diadopsi langsung dari instrument yang diadaptasi dari pola-pola kepribadian oleh Lana Bateman (Personality Plus, 2011) yaitu tipe sanguinis, koleris, melancholis dan phlegmatis, terdapat 40 siswa yang memiliki tipe kepribadian phlegmatis, diantaranya adalah 8 siswa di kelas XI MIA 1, 3 siswa di kelas XI MIA 2, 15 siswa di kelas XI MIA 3, 6 siswa di kelas XI MIA 4, 4 siswa di kelas XI MIA 5 dan 4 siswa di kelas XI MIA 6. Kemudian 40 siswa dari kelas XI MIA 1-6 tersebut diberikan tes soal kemampuan berpikir kritis matematis dan di dapat siswa yang mendapat nilai teringgi dan terendah. Berdasarkan teknik pengambilan sampel yaitu purposive sampling maka peneliti memilih dua orang subjek yang mendapat nilai tertinggi dan nilai terendah tersebut, kemudian dilakukan wawancara.

Siswa yang mendapat nilai tertinggi disebut seperti pada tabel sebabnya dalam penyelesaian soal program linear S.P01 tidak ada melakukan kesalahan dan menjawab dengan benar serta mendapatkan nilai tertinggi. S.P01 menjawab soal nomor 1 dan 2 menjawab soal sesuai dengan indikator kemampuan berpikir kritis yaitu menginterpretasi, menganalisis, mengevaluasi serta menginferensi. Saat melakukan wawancara tahap 2 S.P01 menjawab pertanyaan dengan lancar, dan lantang. Siswa Phlegmatis Kedua Dengan 


\section{$\pi$ (Phi)}

Tingkat Kemampuan Berpikir Kritis Tingkat 0 (Tidak Kritis). Subjek ini memiliki tingkat kemampuan berpikir kritis pada tingkat 0 yaitu tidak kritis. S.P02 memiliki nilai tes kepribadian phlegmatis yaitu nilai kepribadian sanguinis 6 koleris 6 , melancholis, 4 dan phlegmatis 24, maka dikatakan siswa yang memiliki tipe kepribadian phlegmatis yang sangat phlegmatis/tinggi sekali. S.P02 memiliki ciri khas hampir sama dengan S.P01 yaitu pendiam, tapi memperhatikan, kurang semangat dalam suatu hal, sedikit kurang teratur, dan serba dingin, pembawaan diri damai atau tenang, baik apabila dibawah tekanan orang lain dan merupakan pendengar yang baik atau good listeners.

Saat diberikan soal tes kemampuan berpikir kritis matematis tahap 1 ia sangat kesulitan dalam mengerjakannya, atau dalam artian ia tidak paham pada materi pembahasan ini, itulah sebabnya dalam penyelesaian soal program linear S.P02 tidak dapat menjawab dengan benar dan banyak melakukan kesalahan, serta mendapatkan nilai terendah S.P02 menjawab soal nomor 1 dan 2 tidak sesuai dengan indikator kemampuan berpikir kritis yaitu menginterpretasi, menganalisis, mengevaluasi serta menginferensi. Saat melakukan wawancara tahap 2 S.P01 menjawab pertanyaan dengan raut wajah bingung. Saat diberikan soal tes kemampuan berpikir kritis matematis tahap 2 yang setara dengan soal tes kemampuan berpikir kritis tahap 1 ia juga ia sangat kesulitan dalam mengerjakannya, atau dalam artian ia tidak paham pada materi pembahasan ini, itulah sebabnya dalam penyelesaian soal program linear S.P02 tidak dapat menjawab dengan benar dan banyak melakukan kesalahan, serta mendapatkan nilai terendah (dapat dilihat pada lampiran 25) S.P01 menjawab soal nomor 1 dan 2 menjawab soal sesuai dengan indikator kemampuan berpikir kritis yaitu menginterpretasi, menganalisis, mengevaluasi serta menginferensi. Saat melakukan wawancara tahap 2 S.P01 menjawab pertanyaan dengan raut wajah bingung

\section{SIMPULAN DAN SARAN}

Berdasarkan hasil penelitian dapat disimpulkan bahwa kemampuan berpikir kritis matematis siswa berdasarkan tipe kepribadian yang dominan pada penyelesaian soal program linear di kelas XI MIA SMA Negeri 2 Kota Jambi tahun ajaran 2017/2018, dapat diuraikan terlebih dahulu yaitu dari 229 siswa kelas XI MIA 1-6 SMA Negeri 2 Kota Jambi yang mengikuti tes kepribadian diantaranya terdapat 23 siswa bertipe kepribadian lebih dari satu, 53 siswa bertipe kepribadian sanguinis, 37 siswa bertipe kepribadian koleris, 37 siswa bertipe kepribadian melancholis, 79 siswa bertipe kepribadian phlegmatis. Kategori tipe kepribadian phlegmatis yang peneliti ambil yaitu yang memiliki hasil skor tes tipe kepribadian phlegmatis pada gabungan total nilai yaitu skor diatas 15 seperti yang dijelaskan pada buku. Kemudian didapatlah 40 siswa yang bertipe kepribadian dengan ketentuan jumlah skor tersebut.

Kemudian diambil 2 siswa phelgmatis yang memiliki nilai tes kemampuan berpikir kritis matematis yang tertinggi dan terendah, kemudian dilakukan wawancara. Dari hasil wawancara yang telah dilakukan peneliti sebanyak dua kali terhadap subjek penelitian ternyata hasilnya telah meyakinkan peneliti, karena antara data 1 dan data 2 tidak terdapat perbedaan yang signifikan, sehingga terdapat kesesuaian data atau data telah jenuh.

Maka dari itu dapat disimpulkan bahwa siswa phlegmatis pertama mampu pada keempat indikator kemampuan berpikir kritis matematis siswa, sehingga siswa phlegmatis pertama termasuk pada tingkatan kemampuan berpikir kritis tingkat 4 (sangat kritis). Sedangkan siswa 


\section{$\pi$ (Phi)}

phlegmatis kedua tidak mampu pada keempat indikator kemampuan berpikir kritis matematis siswa, sehingga siswa phlegmatis kedua termasuk pada tingkatan kemampuan berpikir kritis tingkat 0 (tidak kritis). Hal ini terlihat bahwa adanya perbandingan terbalik antara tipe kepribadian phlegmatis dengan kemampuan berpikir kritis siswa. Siswa yang memiliki tipe kepribadian phelgmatis yang sangat phlegmatis/sangat tinggi mempunyai tingkat kemampuan berpikir kritis matematis tingkat 0 (tidak kritis). Sedangkan siswa yang memiliki tipe kepribadian phelgmatis cukup phlegmatis mempunyai tingkat kemampuan berpikir kritis matematis tingkat 4 (sangat kritis).

\section{DAFTAR PUSTAKA}

Agustina, Rina. 2014. Penyelesaian Masalah Matematika. Jurnal Pendidikan Matematika FKIP Univ. Muhammadiyah Metro. Vol.3, No.1. Diakses tanggal 3 Januari 2017.

Arikunto, Suharsimi. 2014. Prosedur Penelitian: Suatu Pendekatan Praktik. Jakarta: Rineka Cipta.

Boediono. 2012. Kamus Lengkap Bahasa Indonesia Terbaru. Jakarta: Bintang Indonesia.

Fisher, Alec. 2014. Berpikir Kritis: Sebuah Pengantar. Jakarta: Erlangga.

Hamdi, Muhamad. 2016. Teori Kepribadian: Sebuah Pengantar.

Bandung: Alfabeta.

Hamzah, Ali. 2014. Evaluasi Pembelajaran Matematika. Jakarta: Raja Grafindo Persada.

Johnson, Elaine B. 2014. Contextual Teaching and Learning: Menjadikan Kegiatan Belajar-Mengajar Mengasyikkan dan Bermakna. Bandung: Kaifa Learning.

Kusmanto, Hadi. 2014. Pengaruh Berpikir Kritis Terhadap Kemampuan Siswa Dalam Memecahkan Masalah Matematika. Jurnal EduMa Vol.3
No.1

Lestari, Karunia Eka dan Mokhammad Ridwan Yudhanegara. 2015. Penelitian Pendidikan Matematika. Bandung: Refika Aditama. Littauer, Florence. 2011. Personality Plus (Kepribadian Plus).

Tangerang Selatan: Karisma Publishing Group.

Mahmudati, Rina, Budiyono, dan Subanti, Sri. 2015. Eksperimentasi Model Pembelajaran Kooperatif Tipe Think Pair Share dan Learning Cycle 5E (LC 5E) dengan Pendekatan Saintifik Ditinju Dari Tipe Kepribadian Siswa. Jurnal Elektronik Pembelajaran Matematika. Vol 3, No.3 Diakses tanggal 20 Februari 2017

Moleong, Lexy. J. 2010. Metodologi Penelitian Kualitatif. Bandung: Remaja Rosdakarya.

Rusyna, Adun. 2014. Keterampilan Berpikir: Pedoman Praktis para Peneliti Keterampilan Berpikir. Yogyakarta: Ombak

Dua.

Sudijono, Anas. 2013. Pengantar Evaluasi Pendidikan. Jakarta: PT. Raja Grafindo Persada.

Sugiyono. 2013. Metode Penelitian Kuantitatif, Kualitatif, dan R\&D.

Bandung: Alfabeta.

Sukino. 2014. Matematika untuk SMA/MA

Kelas XI Kelompok Wajib Semester 1. Jakarta: Erlangga.

Suryabrata, Sumadi. 2005. Psikologi Kepribadian. Jakarta: PT. Raja Grafindo Persada.

Susanto, Ahmad. 2013. Teori Belajar dan Pembelajaran di Sekolah Dasar. Jakarta: Kencana Prenada media Group. 